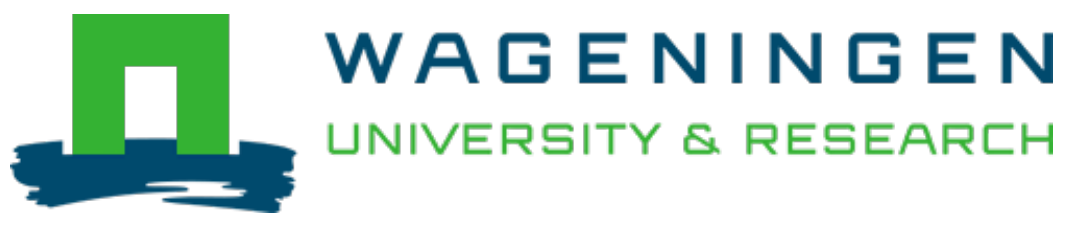

\title{
Fungal growth in silages of sugarbeet press pulp and maize
}

The Journal of Agricultural Science

Nout, M.J.R.; Bouwmeester, H.M.; Haaksma, J.; Dijk, H.

https://doi.org/10.1017/S0021859600085506

This publication is made publicly available in the institutional repository of Wageningen University and Research, under the terms of article $25 \mathrm{fa}$ of the Dutch Copyright Act, also known as the Amendment Taverne. This has been done with explicit consent by the author.

Article $25 \mathrm{fa}$ states that the author of a short scientific work funded either wholly or partially by Dutch public funds is entitled to make that work publicly available for no consideration following a reasonable period of time after the work was first published, provided that clear reference is made to the source of the first publication of the work.

This publication is distributed under The Association of Universities in the Netherlands (VSNU) 'Article $25 \mathrm{fa}$ implementation' project. In this project research outputs of researchers employed by Dutch Universities that comply with the legal requirements of Article $25 \mathrm{fa}$ of the Dutch Copyright Act are distributed online and free of cost or other barriers in institutional repositories. Research outputs are distributed six months after their first online publication in the original published version and with proper attribution to the source of the original publication.

You are permitted to download and use the publication for personal purposes. All rights remain with the author(s) and / or copyright owner(s) of this work. Any use of the publication or parts of it other than authorised under article $25 \mathrm{fa}$ of the Dutch Copyright act is prohibited. Wageningen University \& Research and the author(s) of this publication shall not be held responsible or liable for any damages resulting from your (re)use of this publication.

For questions regarding the public availability of this publication please contact openscience.library@,wur.nl 


\title{
Fungal growth in silages of sugarbeet press pulp and maize
}

\author{
M. J. R. NOUT ${ }^{1}$, H. M. BOUWMEESTER ${ }^{1}$, J. HAAKSMA ${ }^{2}$ AND H. VAN DIJK ${ }^{3}$ \\ ${ }^{1}$ Department of Food Science, Agricultural University, Wageningen, The Netherlands \\ ${ }^{2}$ Institute for Rational Sugar Production, Bergen op Zoom, The Netherlands \\ ${ }^{3}$ Ministry of Agriculture, Natural Resources and Fisheries, Lelystad, The Netherlands
}

(Revised MS received 30 October 1992)

\begin{abstract}
SUMMARY
Fungal spoilage of animal feed silage occurs frequently. In spoiled silage of sugarbeet press pulp sampled in The Netherlands during the period 1986-90, $40 \%$ of the samples were infested by Penicillium roquefortii. Other fungi of health significance included Aspergillus fumigatus $8 \%$ of all samples) and Byssochlamys spp. (4\% of all samples). P. roquefortii is also the dominant spoilage mould in maize silage. However, no PR-toxin could be detected in 25 lumps of $P$. roquefortii-infested maize silage, although one lump contained a fluorescent substance, with an $R_{f}$-value close to that of PR-toxin. This silage sample was not mutagenic, but had a cytotoxic effect towards Salmonella typhimurium in the Ames test. All $P$. roquefortii-infested lumps contained fluorescent fungal metabolites which were absent in samples taken at $5 \mathrm{~cm}$ distance from the corresponding lumps in the silage heaps. It is recommended that lumps of fungal-infested silage are removed before feeding the silage to cattle.
\end{abstract}

\section{INTRODUCTION}

Sugarbeet pulp, a residue of the beet sugar extraction process, is a high-energy animal feed ingredient. About one-third (i.e. 600000 tonnes) of the yearly sugarbeet pulp production in The Netherlands is produced as sugarbeet press pulp with a dry matter (DM) content of $22 \%$. Approximately $30 \%$ of this press pulp is used as fresh pulp and $70 \%$ is preserved as silage. Maize is specifically grown as a fodder crop in The Netherlands, with an estimated yearly production of 10 million tonnes, most of which is chopped and ensiled immediately after harvest. Usually, ensiling is carried out in heaps of $1-1.5 \mathrm{~m}$ height which have been compressed by tractor, and covered with two sheets of $0.15 \mathrm{~mm}$ thick polythene, or one sheet weighted down with a $10-20 \mathrm{~cm}$ layer of soil.

Quite often distinct fungal growth and sporulation can be recognised when opening the heap for use. This fungal growth is indicated by blue, green, orange, red, yellow or white layers, lumps or surface discolorations. Questions from the farmers prompted us to investigate the nature of the fungi occurring in sugarbeet and maize silages, with a view to assessing the possible risk of mycotoxicoses.

\section{MATERIALS AND METHODS}

During the years 1986-89, a total of 120 samples of sugarbeet press pulp silage showing discoloration were received from Dutch farmers. During the period December 1989 to April 1990, maize silage samples from 14 farms were tested specifically for blue-green Penicillium roquefortii-infested lumps. Samples of $c$. $1 \mathrm{~kg}$ were taken from 25 lumps, from silage at $5 \mathrm{~cm}$ and $50 \mathrm{~cm}$ away from the lump. Particulars of the silages including covering material, maize cultivar, dry matter content, particle size, density and feeding rate were recorded.

Penicillium roquefortii strain SP1165, able to produce PR-toxin, was kindly provided by L. Leistner, Bundesforschungsanstalt für Fleischforschung, Kulmbach, Germany, as a reference culture.

Samples of silage with visible fungal growth were suspended in twice their weight of sterile peptonephysiological salt solution containing $5 \mathrm{~g} / 1$ peptone (Oxoid L34) and $8.5 \mathrm{~g} / \mathrm{l} \mathrm{NaCl}$, streaked on three plates of malt extract agar (Oxoid CM59) and incubated at $25^{\circ} \mathrm{C}$ until colonies became visible. Representative colonies were isolated and purified on the same medium. Identification to genus or species level was based on microscopic morphology. 
A $20 \mathrm{~g}$ finely ground sample was extracted with ethylacetate and dichloromethane, purified on a kieselgel column, chromatographed on alufoil kieselgel 60 HPTLC plates (catalogue number 5633.0001, Merck, Darmstadt, Germany) and viewed under a $366 \mathrm{~nm}$ UV light source according to Amend \& Müller (1986). PR-toxin producing Penicillium roquefortii strain SP1165, and PR-toxin (Sigma P4771) were used as reference materials.

A $100 \mathrm{~g}$ sample was extracted according to the method of Filtenborg et al. (1983). The Ames test was carried out according to Ames \& Maron (1982) using Salmonella typhimurium tester strains TA98 and TA100, with and without the addition of S9 liver homogenate.

\section{RESULTS}

From a total of 120 samples of clearly mould-infested silage of sugarbeet press pulp, the major fungal

Table 1. Fungi isolated from mouldy silages of sugarbeet press pulp

\begin{tabular}{lc}
\hline & $\begin{array}{c}\text { Percentage } \\
\text { of total }(n=120)\end{array}$ \\
\hline Identification & 40 \\
Penicillium roquefortii & 23 \\
Mucor spp. & 11 \\
Neurospora spp. & 8 \\
Aspergillus fumigatus & 8 \\
Geotrichum candidum & 4 \\
Monascus ruber & 4 \\
Byssochlamys spp. & 2 \\
Trichoderma spp. & \\
\hline
\end{tabular}

species isolated was Penicillium roquefortii (Table 1). Other fungi, in order of occurrence, were Mucor spp., Neurospora spp., Aspergillus fumigatus, Geotrichum candidum, Monascus ruber, Byssochlamys spp. and Trichoderma spp. P. roquefortii has been divided into two chemotypes (Frisvad 1988). In pure culture on laboratory media, chemotype $\mathrm{I}$ is able to produce PRtoxin, roquefortin $\mathrm{C}$ and mycophenolic acid. Chemotype II can produce patulin, penicillic acid, roquefortin C, mycophenolic acid and botryodiploidin. Pure cultures of $A$. fumigatus can produce a variety of mycotoxins including fumigaclavines, fumitoxins, fumitremorgens, gliotoxin and verruculogen; this genus is also an opportunistic pathogen which has been associated with mycotic abortion in cattle (Counter 1973). Byssochlamys spp. can produce patulin and byssochlamic acid among others. Trichoderma viride can produce trichodermin (Frisvad 1988).

The occurrence of mycotoxins in sugarbeet press pulp silage was not investigated. As $P$. roquefortii was also the most frequent spoilage mould in maize silage, we investigated the presence of PR-toxin, which is regarded as the most acutely toxic metabolite of $P$. roquefortii (Schoch et al. 1984). The particulars of the maize silage heaps with a clearly visible presence of Penicillium roquefortii are listed in Table 2.

Of the 25 samples from the centre of lumps of $P$. roquefortii-infested silage, none contained $\mathrm{PR}$-toxin. However, one sample (14-1A) contained an unidentified fluorescent substance with an $R_{\mathrm{r}}$-value close to that of PR-toxin, possibly a metabolite or degradation product. It was demonstrated that this was not PRtoxin by spiking the sample with reference PR-toxin.

Table 2. Characteristics of maize silage piles sampled on farms in The Netherlands

\begin{tabular}{|c|c|c|c|c|c|c|c|c|}
\hline $\begin{array}{c}\text { Heap } \\
\text { no. }\end{array}$ & Location & $\begin{array}{l}\text { Number } \\
\text { of samples }\end{array}$ & $\begin{array}{l}\text { Maize } \\
\text { cultivar }\end{array}$ & $\begin{array}{l}\text { Dry matter } \\
\text { content }(\%)\end{array}$ & Covering* & $\begin{array}{c}\text { Particle } \\
\text { size† }\end{array}$ & Density $\ddagger$ & $\begin{array}{l}\text { Rate of use } \\
\text { (m/week) }\end{array}$ \\
\hline 1 & Waspik & 2 & Slavis & 29 & PP & 1 & 1 & 1.00 \\
\hline 2 & Rijsbergen & 2 & $\begin{array}{l}\text { Presta }+ \\
\text { Sogetta }\end{array}$ & $28-33$ & PP & 3 & 3 & 1.00 \\
\hline 3 & Heesbeen & 2 & Sonia & $27-32$ & PS & 1 & 1 & - \\
\hline 4 & Nieuwleusen & 1 & LG2080 & 32 & PS & 2 & 2 & 0.90 \\
\hline 5 & Wezep & 2 & Splenda & 29 & PP & 3 & 3 & 1.50 \\
\hline 6 & Goor & 2 & Brutus & 35 & PP & 3 & 1 & 1.50 \\
\hline 7 & Rietmolen & 2 & - & 31 & PS & 2 & 1 & 1.00 \\
\hline 8 & Hellendoorn & 2 & - & 32 & PS & 2 & 2 & 1.50 \\
\hline 9 & Mariënheem & 2 & Sonia & 27 & PS & 3 & 2 & 0.80 \\
\hline 10 & Woudenberg & 2 & Brutus & 28 & PS & 2 & 3 & 1.25 \\
\hline 11 & Varsseveld & 1 & Brutus & 34 & PS & 1 & 1 & 0.80 \\
\hline 12 & Balkbrug-I & 2 & $L G 20+180$ & 30 & PS & 2 & 2 & 0.80 \\
\hline 13 & Balkbrug-II & 1 & Sonia & 30 & PP & 2 & 1 & 1.00 \\
\hline 14 & Dalfsen & 2 & Brutus & 35 & PS & 1 & 1 & $1 \cdot 00$ \\
\hline
\end{tabular}

* Covering: $\mathrm{PP}=$ two polyethylene sheets; $\mathrm{PS}=$ one polyethylene sheet covered with soil.

$\dagger$ Particle size 1 (good) $=<7 \mathrm{~mm} ; 2$ (satisfactory) $=7-10 \mathrm{~mm} ; 3$ (poor) $=>10 \mathrm{~mm}$.

$\ddagger$ Density: 1 (good) $=>200 \mathrm{~kg} \mathrm{DM} / \mathrm{m}^{3} ; 2$ (satisfactory) $=170-200 \mathrm{~kg} \mathrm{DM} / \mathrm{m}^{3} ; 3$ (poor) $=<170 \mathrm{~kg} \mathrm{dm} / \mathrm{m}^{3}$. 
Table 3. Results of Ames test on selected samples of $\mathrm{P}$. roquefortii-infested maize silage

\begin{tabular}{|c|c|c|c|c|c|c|c|c|c|c|c|c|c|}
\hline \multirow{3}{*}{$\begin{array}{c}\text { Sample } \\
14-1 \mathrm{~A}\end{array}$} & \multirow{3}{*}{$\frac{\begin{array}{c}\text { Dose* } \\
\text { (ml extract) }\end{array}}{0}$} & \multicolumn{12}{|c|}{ Number of revertants (triplicates) } \\
\hline & & \multicolumn{3}{|c|}{ TA98 } & \multicolumn{3}{|c|}{ TA98 + \$9 } & \multicolumn{3}{|c|}{ TA 100} & \multicolumn{3}{|c|}{$\mathrm{TA} 100+\mathrm{S} 9+$} \\
\hline & & 25 & 15 & 21 & 33 & 28 & 23 & 89 & 86 & 77 & 61 & 70 & 106 \\
\hline & 0.5 & 19 & 23 & 15 & 18 & 19 & 21 & 7 & 8 & 17 & 51 & 32 & 30 \\
\hline & $1 \cdot 0$ & 17 & 14 & 23 & 23 & 19 & 16 & 4 & 4 & 5 & 19 & 19 & 28 \\
\hline \multirow[t]{3}{*}{$14-2 \mathrm{~A}$} & 0 & 25 & 15 & 21 & 33 & 28 & 23 & 89 & 86 & 77 & 61 & 70 & 106 \\
\hline & 0.5 & 19 & 17 & 31 & 10 & 17 & 15 & 87 & 78 & 84 & 85 & 84 & 79 \\
\hline & $1 \cdot 0$ & 24 & 22 & 18 & 22 & 13 & 16 & 85 & 81 & 82 & 82 & 83 & 89 \\
\hline \multirow[t]{3}{*}{$14-1 B$} & 0 & 32 & 32 & 33 & 37 & 41 & 43 & 115 & 122 & 127 & 143 & 145 & 137 \\
\hline & 0.5 & 25 & 33 & 21 & 33 & 37 & 31 & 117 & 119 & 132 & 125 & 137 & 139 \\
\hline & 1.0 & 35 & 37 & 31 & 25 & 42 & 38 & 121 & 123 & 115 & 153 & 151 & 135 \\
\hline
\end{tabular}

* Dose: $0.5 \mathrm{ml}$ extract corresponds with $2 \mathrm{~g}$ silage; $1 \mathrm{ml}$ extract corresponds with $4 \mathrm{~g}$ silage.

† S9: liver homogenate.

This compound was absent in the corresponding samples 14-1B (taken at $5 \mathrm{~cm}$ distance from the lump containing sample 14-1A) and 14-1C (taken at $50 \mathrm{~cm}$ from the affected lump).

The Ames test was carried out on samples 14-1A (suspect), 14-1B (at $5 \mathrm{~cm}$ distance from the suspect lump) and 14-2A (a similar lump from the same silage heap). No mutagenesis was observed, but sample 14-1A was significantly cytotoxic to $S$. typhimurium strain TA100 (Table 3) at a level corresponding with $2 \mathrm{~g}$ silage.

\section{DISCUSSION}

The predominant fungi associated with visible growth and spoilage in sugarbeet press pulp silage were $P$. roquefortii, Mucor spp. and Neurospora spp. Gedek et al. (1981) also found, in decreasing order of occurrence, $P$. roquefortii (39\% of all samples), Mucorales (16\%), Aspergillus fumigatus $(7 \%)$, Cladosporium spp. (3\%), Monascus purpureus (1.5\%), Paecilomyces varioti (1.5\%), Scopulariopsis brevicaulis $(1.2 \%)$, Trichoderma viride $(0.8 \%)$ and Fusarium moniliforme $(0.8 \%)$ in 260 samples of maize silage.

In maize silages, attention was given only to the occurrence of $\boldsymbol{P}$. roquefortii. In general, all silages were well-covered and well-kept. At the time of opening, the upper surface showed no signs of fungal growth. Almost all of the blue-green lumps were found $20-80 \mathrm{~cm}$ beneath the upper surface. In some silages, the blue-green material was present as a layer. The occurrence of $P$. roquefortii in this area might be the consequence of more favourable environmental conditions such as higher temperature compared to the lower temperature at the upper surface, and lesser density of the silage compared to that at the bottom of the heaps. Similar stratification was also observed in unsealed silos with moist barley (Lacey 1971) where lack of oxygen was suggested as a factor limiting growth in the deeper layers. Possibly a tolerance to increased concentrations of $\mathrm{CO}_{2}$ might contribute to the dominating occurrence of $P$. roquefortii. Silages with $P$. roquefortii represented a range of maize cultivars, so there was no reason to suspect a varietal effect. Spoiled silages did not differ in DM content from the mean of all silages ( $32.6 \% \mathrm{DM})$; the particle size (chopping rate) was not visually different from that of sound silages. However, in many of the spoiled silages the rate of use was lower than that usually recommended (i.e. $\geqslant 1.5 \mathrm{~m} /$ week for silages with a soil top cover, or $\geqslant 2 \mathrm{~m} /$ week for silages without soil top cover). We assume therefore that the $P$. roquefortii spoilage is produced when the rate of use is too slow, and that fungal growth may progress into the silage heap starting from the surface where silage is cut away for use. The unloading rate was also a major factor influencing fungal growth in moist barley (Lacey 1971).

Although none of the blue-green lumps showed the presence of PR-toxin, one lump contained a fluorescent substance which might have been closely related to PR-toxin.

Amend \& Müller (1986) found significantly lower levels of PR-toxin in maize silage compared to pure cultures. They ascribed this discrepancy to the instability of PR-toxin in the presence of proteins, amino acids and amines. Also $\mathrm{pH}$ values $<3$ destabilize PR-toxin.

In the Ames test, PR-toxin is mutagenic and cytotoxic to the liver and human cell lines (Schoch $e t$ al. 1984). In this study, silage sample 14-1A was not mutagenic, but it had a cytotoxic effect on Salmonella typhimurium TA100. A blue-green $P$. roquefortii lump from the same silage heap did not show this behaviour. This apparent heterogeneity could be associated with the fact that only chemotype I of $P$. roquefortii is able to produce PR-toxin (Frisvad 1988). It is also possible that PR-toxin is first produced, and subsequently metabolized as was 
observed by Wei \& Liu (1978). They found that of four tested strains of $P$. roquefortii, all were able to produce PR-toxin in pure culture, but the level of PRtoxin fell to zero 1-2 days after having reached its maximum. Also, Gedek et al. (1981) observed that all of 34 isolated strains were able to produce PR-toxin, whereas only two isolates produced roquefortin. In principle, it thus is possible that $P$. roquefortii leaves no detectable traces of PR-toxin but that toxin degradation products remain in the silage; no data are available on the toxicity of such degradation products. All samples taken from the centre of lumps contained fluorescent substances which were not present in fresh maize and which therefore were probably formed by $P$. roquefortii. In samples taken 5 and $50 \mathrm{~cm}$ away from lumps, such fluorescent compounds were absent. We conclude therefore that these metabolites do not diffuse outside the lumps of spoiled maize silage. The same conclusion can be drawn with regard to the substance responsible for the cytotoxic effect.

Although PR-toxin was absent, there is a certain risk of toxicity associated with the consumption of silage lumps containing $P$. roquefortii. Toxic effects of $P$. roquefortii-infested maize silage in milk cattle included feed refusal, reduced rumen fermentation activity, intestinal inflammation, mastitis and abortion (Vesely et al. 1981; Häggblom 1990). Since it appears that $P$. roquefortii metabolites do not migrate outside the infested material, it is recommended that clearly (blue-green) fungal-infested silage is removed before feeding silage to cattle.

Part of this study was supported financially by Stichting Nederlands Graan-Centrum, Wageningen, The Netherlands.

\section{REFERENCES}

AMEND, R. \& MülleR, H. M. (1986). Anhäufung von PRtoxin und Mycophenolsäure durch Penicillien im YESmedium und in Grünmaissilage. Landwirtschaftliche Forschung 37, Sonderheft No. 41, 606-614.

AMES, B. N. \& MARoN, D. M. (1982). Revised methods for the Salmonella mutagenicity test. Mutation Research 113 , 173-215.

CoUnter, D. E. (1973). An outbreak of mycotic abortion apparently due to mould-infested sugarbeet pulp. Veterinary Record 93, 425.

FiltenborG, O., Frisvad, J. C. \& Svendsen, J. A. (1983). Simple screening method for molds producing intracellular mycotoxins in pure cultures. Applied and Environmental Microbiology 45, 581-585.

Frisvad, J. C. (1988). Fungal species and their specific production of mycotoxins. In Introduction to Food-borne Fungi (Eds R. A. Samson \& E. S. van Reenen-Hoekstra), pp. 239-249. Baarn, The Netherlands: Centraalbureau voor Schimmelcultures.
Gedek, B., Bauer, J. \& Schreiber, H. (1981). Zur Mykotoxinbildung Silage-verderbender Schimmelpilze. Wiener Tierärztliche Monatsschrift 68, 299-301.

HäGGblom, P. (1990). Isolation of roquefortine C from feed grain. Applied and Environmental Microbiology 56, 2924-2926.

LACEY, J. (1971). The microbiology of moist barley storage in unsealed silos. Annals of Applied Biology 69, 187-212.

Schoch, U., LUThy, J. \& SChlatter, C. (1984). Mutagenicity testing of commercial Penicillium camemberti and Penicillium roquefortii strains. Zeitschrift für Lebensmittel-Untersuchung und-Forschung 178, 351-355.

Vesely, D., Vesela, D. \& Adamkova, A. (1981). Fund des das PR-toxin produzierenden Schimmelpilzes Penicillium roquefortii in Maissilagen. Veterinárni Medicina Praha 26, 110-115.

WEI, R-D. \& LIU, G-X. (1978). PR toxin production in different Penicillium roquefortii strains. Applied and Environmental Microbiology 35, 797-799. 